\title{
ine \\ Bioactive Properties of Peptides and Polysaccharides Derived from Peanut Worms: A Review
}

\author{
Yi Qi ${ }^{1,2,+}$, Jingyi Zhou ${ }^{1,+}$, Xiaoqin Shen ${ }^{3}$, Meram Chalamaiah ${ }^{4}$, Simin Lv ${ }^{5}$, Hui Luo ${ }^{1,2}$ and Liang Chen ${ }^{1, *}$ \\ 1 The Marine Biomedical Research Institute, Guangdong Medical University, Zhanjiang 524023, China; \\ qiyi7272@gdmu.edu.cn (Y.Q.); nancy197@163.com (J.Z.); luohui@gdmu.edu.cn (H.L.) \\ 2 Marine Chinese Medicine Branch, National Engineering Research Center for Modernization of Traditional \\ Chinese Medicine, Zhanjiang 524023, China \\ 3 College of Pharmacy, Guangdong Medical University, Zhanjiang 524023, China; sxq11192021@163.com \\ 4 4-10 Ag/For Centre, Department of Agricultural, Food and Nutritional Science (AFNS), University of Alberta, \\ Edmonton, AB T6G 2P5, Canada; chalamaiah.m@gmail.com \\ 5 Guangdong Runyuan Zhongtian Biological Technology Co., Ltd., Dongguan 523808, China; \\ lvsimin88@126.com \\ * Correspondence: cliang@gdmu.edu.cn \\ + These authors contributed equally to this work.
}

Citation: Qi, Y.; Zhou, J.; Shen, X.; Chalamaiah, M.; Lv, S.; Luo, H.; Chen, L. Bioactive Properties of Peptides and Polysaccharides Derived from Peanut Worms: A Review. Mar. Drugs 2022, 20, 10. https://doi.org/ $10.3390 / \mathrm{md} 20010010$

Academic Editors: Yuki Fujii,

Marco Gerdol and Yasuhiro Ozeki

Received: 27 November 2021

Accepted: 15 December 2021

Published: 22 December 2021

Publisher's Note: MDPI stays neutral with regard to jurisdictional claims in published maps and institutional affiliations.

Copyright: (C) 2021 by the authors. Licensee MDPI, Basel, Switzerland. This article is an open access article distributed under the terms and conditions of the Creative Commons Attribution (CC BY) license (https:// creativecommons.org/licenses/by/ $4.0 /)$.

\begin{abstract}
Peanut worms (Sipunculids) are unsegmented marine worms that usually inhabit shallow waters. Peanut worms are good source of bioactive compounds including peptides and polysaccharides. Many recent studies have investigated the bioactive properties of peptides and polysaccharides derived from peanut worms in order to enhance their applications in food and pharmaceutical industries. The peptides and polysaccharides isolated from peanut worms have been reported to possess anti-hypertensive, anti-oxidant, immunomodulatory, anti-inflammatory, anti-cancer, antihypoxia and wound healing activities through the modulation of various molecular mechanisms. Most researchers used in vitro, cell culture and animal models for the determination of bioactivities of peanut worm derived compounds. However, studies in humans have not been performed considerably. Therefore, it is important to conduct more human studies for better utilization of marine bioactive compounds (peptides and polysaccharides) derived from peanut worms. This review mainly focuses on the bioactive properties of peptides and polysaccharides of peanut worms and their molecular mechanisms.
\end{abstract}

Keywords: marine worms; sipunculids; bioactive properties; peptides; polysaccharides

\section{Introduction}

Peanut worms are a group of unsegmented marine worms that belong to the invertebrate phylum Sipuncula. There are about 162 species of peanut worms. They are mostly under $10 \mathrm{~cm}$ long and live in shallow waters. Peanut worms are edible and considered as a delicacy in several southeast Asian countries including China, Philippines and Vietnam [1]. Some peanut worms (e.g., Sipunculus nudus) have been used in traditional Chinese medicine for the treatment/management of various ailments including hypertension, neurosis, coughing with dyspnea, nocturia, carbuncles, sternalgia, physical weakness, tuberculosis and regulating the functions of stomach and spleen [1,2].

Nutritional composition of foods plays an important role in providing essential nutrients for maintaining good health. The nutritional/chemical composition of peanut worms has been investigated [1,3]. The major components of peanut worms are proteins, carbohydrates and ash. For example, the protein content of P. esculenta was found to be $74.5 \%$ with high quality amino acids, and carbohydrates were $6.2 \%$ [3]. Since peanut worms contain significant quantities of nutritional and bioactive compounds, it is important to exploit the peanut worms for identification and isolation of active bioactive compounds for various food and pharmaceutical applications. 
Many recent investigations have demonstrated the isolation of diverse peptides and polysaccharides, with various biological properties such as anti-oxidant, anti-cancer, immunomodulatory, anti-inflammatory and anti-hypertensive activities, from a number of marine organisms with great potential for industrial and therapeutic applications [4-6]. Food derived bioactive peptides are usually short chains of amino acids and generally possess 2-20 amino acid residues. Bioactive peptides are inactive within the sequence of parent protein. However, the bioactive peptides can be generated by using in vitro enzymatic hydrolysis, fermentation and during food processing and gastrointestinal digestion. In vitro enzymatic hydrolysis is the most widely used method for the production of bioactive peptides from various food sources. Bioactive peptides are easily digestible and absorbable with less or no side effects [7]. Therefore, recently bioactive peptides have attracted great interest among scientists and consumers due to their health benefiting properties [8]. Numerous bioactive peptides with diverse health promoting properties have been reported from various marine species and other food sources including fish, molluscs, crustaceans, algae, milk, egg and plant sources $[7,9,10]$.

Polysaccharides are complex natural macromolecular polymers composed of monosaccharide units linked by glycosidic bonds. Polysaccharides are widely present in plants, animals, microorganisms and marine organisms and play a vital role in the development of living organisms [11]. In recent years, polysaccharides derived from natural sources have attracted great attention due to their biocompatibility, non-toxicity, biodegradability and applications in food and pharmaceutical industries [12]. It has been documented that polysaccharides isolated from natural edible sources exhibit significant bioactive properties [13].

Several recent studies have demonstrated that the peptides and polysaccharides obtained from peanut worms possessed numerous health benefiting functions, namely, antiinflammatory, anti-hypertensive, immunomodulatory, anti-cancer, wound healing, antioxidant and anti-hypoxia activities [14-20] (Figure 1). However, the biological properties of peptides and polysaccharides of peanut worms have not been reviewed in the literature so far. This prompted the authors to review the literature on various bioactivities of peptides and polysaccharides derived from peanut worms and their molecular mechanisms of action.

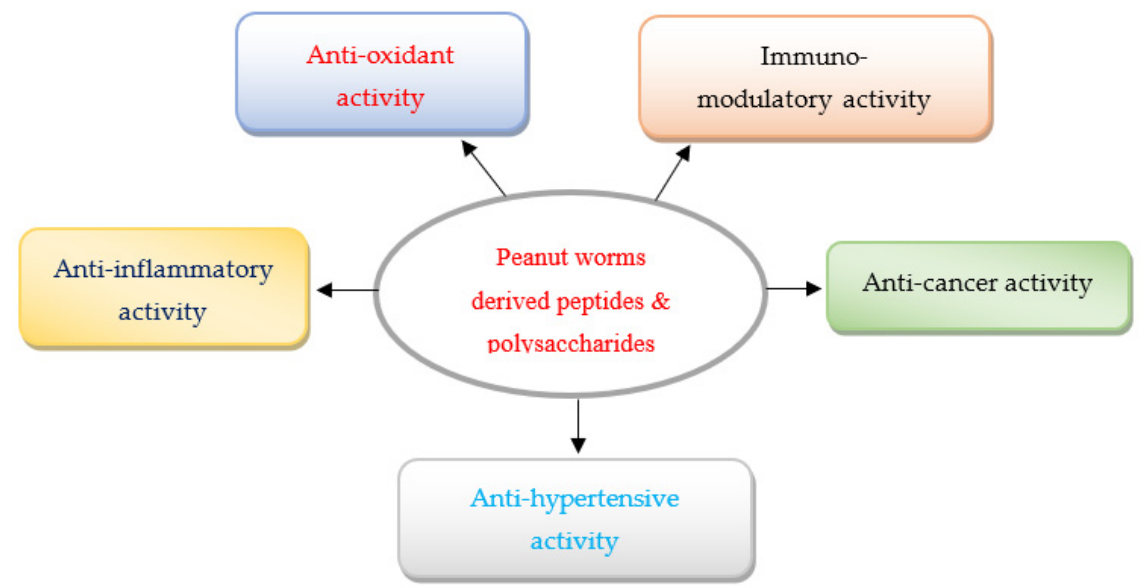

Figure 1. Various major bioactivities of peptides and polysaccharides derived from peanut worms.

\section{Anti-Oxidative Properties of Peptides and Polysaccharides Derived from Peanut Worms}

Cellular respiration in humans and other aerobic organisms generates reactive oxygen species (ROS) and free radicals. The anti-oxidant mechanisms (e.g., superoxide dismutase, catalase and glutathione peroxidase) in the body neutralize the excess production of free radicals and thereby maintain the balance between antioxidants and oxidative stress. The ROS and free radicals contain unpaired electrons and cause damage to important cellular components including lipids, proteins and DNA. The over production of ROS and free radicals has been linked to various diseases such as cancer, diabetes, atherosclerosis, Alzheimer disease and cardiovascular disorders [21-23]. Recently, there has been great interest in 
identification and isolation of anti-oxidant bioactive compounds from natural food sources (marine organisms, fish, milk, egg, algae, plant sources) due to their increased applications as safe alternatives to synthetic anti-oxidants in food and pharmaceutical industries.

Numerous peptides and polysaccharides with anti-oxidant activities have been identified and isolated from marine organisms for application as functional foods/health foods [24-26]. Peptides play an important role in the inhibition of free radicals and oxidative stress. It has been reported that the anti-oxidant mechanism of food originated peptides depends on composition, sequence and length [27,28]. Additionally, it was demonstrated that peptides with more hydrophobic (Ala, Val, Gly, Leu, Ile, Phe, Pro) amino acid residues can enhance anti-oxidant ability $[15,29,30]$. Most anti-oxidant peptides possess 3-15 amino acid residues [27,31-34]. Table 1 shows the molecular mechanisms of anti-oxidant peptides produced from various peanut worms.

Table 1. Molecular mechanisms of anti-oxidant peptides derived from peanut worms.

\begin{tabular}{|c|c|c|c|c|c|c|}
\hline $\begin{array}{l}\text { Peanut } \\
\text { Worm } \\
\text { Name }\end{array}$ & $\begin{array}{l}\text { Enzyme Used } \\
\text { to Produce } \\
\text { Peptides }\end{array}$ & $\begin{array}{l}\text { Peptide Sequence } \\
\text { and Molecular } \\
\text { Weight }\end{array}$ & $\begin{array}{l}\text { In Vitro/Cell Culture/ } \\
\text { Animals/Humans } \\
\text { Used for the Study }\end{array}$ & $\begin{array}{l}\text { Dose and } \\
\text { Duration }\end{array}$ & $\begin{array}{l}\text { Mechanism of Action/ } \\
\text { Activities/Effects } \\
\text { Showed }\end{array}$ & Ref. \\
\hline $\begin{array}{l}\text { Sipunculus } \\
\text { nudus }\end{array}$ & Papain & Peptides $5868 \mathrm{Da}$ & $\begin{array}{c}\text { In vitro hydroxyl } \\
\text { Radical scavenging } \\
\text { activity }\end{array}$ & $\longrightarrow$ & $\begin{array}{l}\text { The polypeptide showed } \\
\text { great hydroxyl radical } \\
\text { scavenging activity with } \\
95.42 \% \text { inhibition. }\end{array}$ & [35] \\
\hline $\begin{array}{l}\text { Phascolosoma } \\
\text { esculenta }\end{array}$ & Pancreatin & Peptides $<3 \mathrm{kDa}$ & Mice & $\begin{array}{l}50,100 \text { and } \\
150 \mathrm{mg} / \mathrm{kg} \\
\text { for } 15 \text { days }\end{array}$ & $\begin{array}{l}\text { Peptides dose-dependently } \\
\text { improved the oxidative } \\
\text { stress status (GSH-Px, SOD, } \\
\text { TAC andMDA) in mice }\end{array}$ & [15] \\
\hline $\begin{array}{l}\text { Phascolosoma } \\
\text { esculenta }\end{array}$ & Papain & & $\begin{array}{c}\text { In vitro total } \\
\text { anti-oxidant capacity }\end{array}$ & & $\begin{array}{l}\text { Collagen peptides from } \\
\text { Phascolosoma esculenta } \\
\text { showed total anti-oxidant } \\
\text { capacity with } 3.8 \mathrm{U} / \mathrm{mg}\end{array}$ & [36] \\
\hline
\end{tabular}

There have been several investigations that reported the anti-oxidant capacity of peptides derived from peanut worms. The anti-oxidant activities exhibited by the peanut worms derived peptides were due to the inhibition of free radicals and enhancing the secretion of endogenous antioxidant enzymes such as SOD and glutathione peroxidase (GSH-Px). Zhu et al. [35] produced peptides from Sipunculus nudus by hydrolyzing with papain and found that peptides with molecular weight of $5868 \mathrm{Da}$ showed excellent hydroxyl radical scavenging activity with 95\% inhibition. Peptides generated from collagen of Phascolosoma esculenta have been reported to possess anti-oxidant capacity in vitro [36]. Liu et al. [15] prepared peptides $(<3 \mathrm{kDa})$ from Phascolosoma esculenta by using pancreatin and investigated the anti-oxidant capacity of the peptides using mice model. It was found that peptide's administration at 50, 100 and $150 \mathrm{mg} / \mathrm{kg}$ for 15 days dose-dependently improved the oxidative stress parameters such as GSH-Px, SOD, TAC and MDA in mice.

Apart from peptides, many studies have demonstrated that polysaccharides derived from peanut worms exhibit antioxidant activity through several ways including inhibition of DPPH, hydroxyl, superoxide free radicals, having reducing power, enhancing the antioxidant enzymes such as superoxide dismutase, glutathione peroxidase and upregulation of Nrf2 signaling pathway $[16,19,37,38]$. Anti-oxidant properties of polysaccharides produced from various peanut worms are presented in Table 2. 
Table 2. Molecular mechanisms of anti-oxidant activities of polysaccharides derived from various peanut worms.

\begin{tabular}{|c|c|c|c|c|c|}
\hline Source & $\begin{array}{c}\text { Composition of Polysaccharide } \\
\text { Extract }\end{array}$ & $\begin{array}{l}\text { Cell Culture/ } \\
\text { Animal Models }\end{array}$ & Dose and Duration & Molecular Mechanisms/Effects & Ref. \\
\hline Sipunculus nudus & $\begin{array}{l}\text { Polysaccharide was com-posed of } \\
\text { mannose, rhamnose, galacturonic } \\
\text { acid, glucose, arabinose and fucose }\end{array}$ & $\begin{array}{l}\text { In vitro hydroxyl radical } \\
\text { activity. }\end{array}$ & $\begin{array}{l}0.25,0.5,1.0,2.0 \\
5.0,10.0,20.0 \mathrm{mg} / \mathrm{mL} \\
\text { for } 30 \mathrm{~min}\end{array}$ & $\begin{array}{l}\text { Polysaccharide showed powerful scavenging activity on } \\
\text { hydroxyl radical in a dose dependent manner. }\end{array}$ & [39] \\
\hline Sipunculus nudus & $\longrightarrow$ & $\begin{array}{l}\text { In vitro reducing power, } \\
\text { hydroxyl and superoxide } \\
\text { radicals inhibition assay }\end{array}$ & $\begin{array}{l}200-1000 \mu \mathrm{g} / \mathrm{mL} \text { for } \\
30 \mathrm{~min}\end{array}$ & $\begin{array}{l}\text { S. nudus polysaccharides showed dose dependent } \\
\text { inhibition of hydroxyl and superoxide radicals and } \\
\text { exhibited great reducing power. }\end{array}$ & [37] \\
\hline Phascolosoma esculenta & $\begin{array}{l}\text { D-glucosyl, D-galactosyl, with small } \\
\text { amount of D-mannosyl, } \\
\text { D-arabinosyl and residues with a- } \\
\text { and b-type linkage. }\end{array}$ & Mice & $\begin{array}{l}1,10 \text { and } 5 \mathrm{mg} / \mathrm{mL} \text { for } \\
30 \text { days }\end{array}$ & $\begin{array}{l}\text { Oligosaccharides from Phascolosoma esculenta enhanced the } \\
\text { enzyme activities of GSH-Px and SOD by upregulating } \\
\text { Nrf2 mRNA expression in sepsis mice model. }\end{array}$ & [16] \\
\hline Phascolosoma esculenta & $\begin{array}{l}\text { Mannose, ribose, rhamnose, } \\
\text { glucuronic acid, glucose, galactose, } \\
\text { xylose, arabinose and fucose }\end{array}$ & $\begin{array}{l}\text { In vitro DPPH, superoxide } \\
\text { anion, hydroxyl radicals } \\
\text { and ferrous ion chelating } \\
\text { and mice model }\end{array}$ & $\begin{array}{c}0.2,0.4 \text { and } \\
0.8 \mathrm{~g} / \mathrm{kgBW} \text { for } 25 \mathrm{~d}\end{array}$ & $\begin{array}{c}\text { Polysaccharides from Phascolosoma esculenta scavenged free } \\
\text { radicals dose-dependently and showed antioxidant } \\
\text { activities in mice by enhancing superoxide dismutase } \\
\text { (SOD) (10.2-22.2\% and 18.8-26.9\%), glutathione peroxidase } \\
\text { (GSH-Px) (11.9-15.4\% and 26.6-30.4\%) activities in serum } \\
\text { and liver. }\end{array}$ & [38] \\
\hline Phascolosoma esculenta & $\begin{array}{l}\text { polysaccharide contained glucose } \\
\text { with acetylaminoand pyran rings } \\
\text { and connected by } \alpha \text {-glycosidic bonds }\end{array}$ & $\begin{array}{l}\text { In vitro reducing power, } \\
\text { DPPH and hydroxyl radical } \\
\text { scavenging activities }\end{array}$ & $\begin{array}{l}1,5,10,15,20 \text {, and } \\
25 \mathrm{mg} / \mathrm{mL} \text { for } 30 \mathrm{~min}\end{array}$ & $\begin{array}{c}\text { Polysaccharide showed DPPH and hydroxyl radical } \\
\text { scavenging and reducing power with } \mathrm{IC}_{50} \text { of } 0.567 \text { and } \\
0.605,2.976 \mathrm{mg} / \mathrm{mL} \text {, respectively. }\end{array}$ & [19] \\
\hline
\end{tabular}


Researchers used various in vitro, and animal models to study the antioxidant capacity of polysaccharides derived from peanut worms. Studies conducted by Li et al. [39] and Qin et al. [37] documented that polysaccharides extracted from Sipunculus nudus showed a dose dependent inhibition of hydroxyl and superoxide radicals. Zhihao et al. [16] found that oligosaccharides from Phascolosoma esculenta exhibited anti-oxidative effects in sepsis mice model through the enhancement of enzyme activities of GSH-Px and SOD by activation of Nrf2 signaling pathway. Polysaccharide, composed of mannose, ribose, rhamnose, glucuronic acid, glucose, galactose, xylose, arabinose and fucose, derived from Phascolosoma esculenta have shown antioxidant activities in mice by enhancing superoxide dismutase $(10-26 \%)$, glutathione peroxidase (11-30\%) activities in serum and liver [38]. In a recent study, Yiqiao et al. [19] determined the radical scavenging activity and reducing power of polysaccharide isolated from Phascolosoma esculenta and reported the $\mathrm{IC}_{50}$ values of 0.567 and $0.605,2.976 \mathrm{mg} / \mathrm{mL}$ respectively for DPPH and hydroxyl radicals and reducing power.

Most studies used in vitro and mice models for the determination of anti-oxidant activity of peptides and polysaccharides from peanut worms. However, cell culture and human studies are scanty. Therefore, further research is needed in humans and cells to verify the anti-oxidant benefits of these bioactive compounds of peanut worms.

\section{Anti-Inflammatory Activities of Peptides and Polysaccharides Derived from Peanut Worms}

Inflammation is a natural and complex defense mechanism of the immune system against a variety of harmful stimuli including pathogens, damaged cells, toxic chemicals, and irradiation. Generally, acute inflammation is beneficial to the body. However, chronic and uncontrolled inflammation can lead to various diseases such as cancer, diabetes, atherosclerosis, chronic kidney disease, arthritis and neurodegenerative disorders [40,41]. NSAIDs (non-steroidal anti-inflammatory drugs) are commonly used drugs for the treatment of inflammation. However, side effects associated with cardiovascular/renal/gastrointestinal systems have limited the application of NSAIDs. Therefore, recently there is a great interest in the use of food derived bioactive components (e.g., peptides and polysaccharides) for treatment or management of inflammation/inflammatory diseases due to their food origin and no/less side effects. Research has revealed that food derived bioactive compounds play an important role in the mitigation of inflammation/inflammatory diseases.

Numerous recent studies have shown that bioactive compounds (peptides, polyphenols, proteins, lipids and polysaccharides) derived from several food sources (fish, milk, egg, marine organisms and plant foods) possess anti-inflammatory properties [42-46]. Marine peanut worms have been investigated for anti-inflammatory compounds. Peptides and polysaccharides isolated from peanut worms have demonstrated to modulate the inflammatory response by inhibiting the production of pro-inflammatory mediators, TNF- $\alpha$, IL- $1 \beta$ and TGF- $\beta 1$, and reducing the activity of enzymes, cyclooxygenase- 2 (COX-2) and inducible nitric oxide synthase (iNOS).

Recently, anti-inflammatory peptides have been identified and isolated from few peanut worms after hydrolysis with proteolytic enzymes. Peptides isolated from Sipunculus nudus have shown anti-inflammatory effects through the modulation of several mechanisms such as reduction of expression of pro-inflammatory mediators, TNF- $\alpha$, IL-1 $\beta$, IL-6, iNOS and COX-2 and inhibition of NO production $[1,20]$. The anti-inflammatory effects of peptides isolated from peanut worms are presented in Table 3.

The food originated anti-inflammatory peptides are usually 2-10 amino acids in length. In addition to the peptide's length, composition and sequence of peptides also play an important role in anti-inflammatory activity $[47,48]$. In recent years, researchers have documented the extraction of anti-inflammatory peptides from peanut worm, Sipunculus nudus. Sangtanoo et al. [1] isolated two peptides, LSPLLAAH (821.48 Da) and TVNLAYY (843.42 Da), from Sipunculus nudus after hydrolysis with neutrase, flavourzyme, and Alcalase and re- 
ported that both peptides showed strong anti-inflammatory activity in LPS-stimulated RAW264.7 macrophages by decreasing the expression of pro-inflammatory mediators, iNOS, IL-6, TNF- $\alpha$ and COX-2 after treatment with 30, 60, $120 \mathrm{mM}$ for $12 \mathrm{~h}$. In another recent study, Lin et al. [20] produced collagen peptides from Sipunculus nudus by using animal hydrolytic protease and flavor protease and demonstrated that peptides inhibited inflammation in the wound of mice skin through the reduction of mRNA levels of TGF- $\beta 1$, TNF- $\alpha$ and IL- $1 \beta$.

Table 3. Molecular mechanisms of anti-inflammatory peptides derived from peanut worms.

\begin{tabular}{|c|c|c|c|c|c|c|}
\hline $\begin{array}{l}\text { Peanut } \\
\text { Worm } \\
\text { Name }\end{array}$ & $\begin{array}{l}\text { Enzyme Used to } \\
\text { Produce } \\
\text { Peptides }\end{array}$ & $\begin{array}{c}\text { Peptide Sequence } \\
\text { and Molecular } \\
\text { Weight }\end{array}$ & $\begin{array}{l}\text { In Vitro/Cell Culture/ } \\
\text { Animals/Humans } \\
\text { Used for the Study }\end{array}$ & $\begin{array}{l}\text { Dose and } \\
\text { Duration }\end{array}$ & $\begin{array}{c}\text { Mechanism of } \\
\text { Action/Activities/Effects } \\
\text { Showed }\end{array}$ & Ref. \\
\hline $\begin{array}{l}\text { Sipunculus } \\
\text { nudus }\end{array}$ & $\begin{array}{l}\text { Neutrase, } \\
\text { Flavourzyme, } \\
\text { and Alcalase }\end{array}$ & $\begin{array}{l}\text { LSPLLAAH } \\
\text { (821.48 Da) and } \\
\text { TVNLAYY } \\
(843.42 \mathrm{Da})\end{array}$ & $\begin{array}{l}\text { RAW } 264.7 \\
\text { macrophages }\end{array}$ & $\begin{array}{l}30,60 \\
120 \mathrm{~mm} \\
\text { for } 12 \mathrm{~h}\end{array}$ & $\begin{array}{l}\text { Peptides (LSPLLAAH and } \\
\text { TVNLAYY) inhibited NO } \\
\text { production and decreased the } \\
\text { expression of pro-inflammatory } \\
\text { mediators, iNOS, IL-6, TNF- } \alpha \text {, } \\
\text { and COX-2, in LPS-stimulated } \\
\text { RAW264.7 macrophages. }\end{array}$ & [1] \\
\hline $\begin{array}{l}\text { Sipunculus } \\
\text { nudus }\end{array}$ & $\begin{array}{c}\text { Animal } \\
\text { hydrolytic } \\
\text { protease } \\
(3000 \mathrm{U} / \mathrm{g}) \text { and } \\
\text { flavor protease }\end{array}$ & $\begin{array}{c}\text { Collagen } \\
\text { peptides }<5 \mathrm{kDa}\end{array}$ & Mice & $\begin{array}{l}2 \mathrm{~g} / \mathrm{mL} \\
\text { for } \\
7 \text { days }\end{array}$ & $\begin{array}{l}\text { Peptides showed } \\
\text { anti-inflammatory activity } \\
\text { through the reduction of } \\
\text { mRNA levels of TGF- } \beta 1 \text {, } \\
\text { TNF- } \alpha \text { and IL-1 } \beta \text { in the } \\
\text { wound of mice skin. }\end{array}$ & [20] \\
\hline
\end{tabular}

Apart from the peptides, the anti-inflammatory effects of polysaccharides isolated from peanut worms have also been studied considerably in recent years (Table 4). ChenXiao et al. [2] investigated the anti-inflammatory activities of water soluble polysaccharides of Sipunculus nudus using different mouse and rat models of inflammation. It was found that polysaccharide treatment at 50, 100 and $200 \mathrm{mg} / \mathrm{kgBW}$ for 6 days dose-dependently reduced the inflammation of carrageenan-induced paw oedema, dextran-induced rat paw oedema, carrageenan-induced peritonitis, xylene-induced ear oedema, and acetic acid-induced vascular permeability in mice. Zhihao et al. [16] extracted oligosaccharides, composed of D-glucosyl, and D-galactosyl residues with $\alpha$ - and $\beta$-type linkages, from Phascolosoma esculenta and demonstrated that administration of oligosaccharides at 1,10 and $5 \mathrm{mg} / \mathrm{mL}$ for 30 days noticeably decreased the production of IL- $1 \beta$ and TNF- $\alpha$ and enhanced IL-10 in mice with sepsis induced inflammation.

The anti-inflammatory properties shown by the peptides and polysaccharides of peanut worms could be due to the suppression of nuclear factor kappa B (NF- $\mathrm{kB}$ ) activation. Inhibition of NF- $\mathrm{KB}$ activation decreases the expression of COX-2 and iNOS and production of TNF- $\alpha$ and IL-1 $\beta$, and therefore reduces inflammation. Though the anti-inflammatory activities have been reported for the peptides and polysaccharides of peanut worms, the underlying molecular mechanisms of anti-inflammatory activity have not been explored extensively so far. Therefore, further research is needed to determine the exact molecular mechanisms of action of these anti-inflammatory bioactive components (peptides and polysaccharides) isolated from peanut worms. This would enhance the applications of these bioactive compounds in food and pharmaceutical industries. 
Table 4. Molecular mechanisms of anti-inflammatory activity of polysaccharides derived from various peanut worms.

\begin{tabular}{|c|c|c|c|c|c|}
\hline Source & $\begin{array}{c}\text { Composition of } \\
\text { Polysaccharide Extract }\end{array}$ & $\begin{array}{l}\text { Cell Culture/ } \\
\text { Animal Models }\end{array}$ & $\begin{array}{l}\text { Dose and } \\
\text { Duration }\end{array}$ & Molecular Mechanisms/Effects & Ref. \\
\hline $\begin{array}{l}\text { Sipunculus } \\
\text { nudus }\end{array}$ & Water extract & $\begin{array}{l}\text { Mouse and rat } \\
\text { oedema paw } \\
\text { models }\end{array}$ & $\begin{array}{l}50,100 \text { and } \\
200 \mathrm{mg} / \mathrm{kg} \\
\text { for } 6 \text { days }\end{array}$ & $\begin{array}{l}\text { Water extract from the body wall of } \\
\text { Sipunculus nudus showed dose-dependent } \\
\text { anti-inflammatory activity in the } \\
\text { carrageenan-induced paw oedema, } \\
\text { dextran-induced rat paw oedema, cotton } \\
\text { pellet granuloma, carrageenan-induced } \\
\text { peritonitis, xylene-induced ear oedema, } \\
\text { and acetic acid-induced vascular } \\
\text { permeability models. }\end{array}$ & [2] \\
\hline $\begin{array}{c}\text { Phascolosoma } \\
\text { esculenta }\end{array}$ & $\begin{array}{l}\text { D-glucosyl, D-galactosyl, } \\
\text { with small amount of } \\
\text { D-mannosyl, D-arabinosyl } \\
\text { and residues with } \alpha \text { - and } \\
\beta \text {-type linkage. }\end{array}$ & Mice & $\begin{array}{l}1,10 \text { and } \\
5 \mathrm{mg} / \mathrm{mL} \\
\text { for } 30 \text { days }\end{array}$ & $\begin{array}{l}\text { Oligosaccharides from Phascolosoma } \\
\text { esculenta considerably decreased the } \\
\text { secretion of IL- } 1 \beta \text { and TNF- } \alpha \text { and } \\
\text { enhanced the IL- } 10 \text { in sepsis mice. }\end{array}$ & [16] \\
\hline
\end{tabular}

\section{Anti-Hypertensive Activity of Peptides from Peanut Worms}

Hypertension (high blood pressure) is a serious medical condition that affects 1280 million people globally aged between 30-79 years. It has been reported that several diseases related to heart (myocardial infarction, coronary heart disease), brain (stroke) and kidney (kidney failure) are linked to hypertension. Angiotensin I-converting enzyme (ACE; EC 3.4.15.1) plays an important role in regulation of blood pressure. ACE cleaves the two C-terminal dipeptides of inactive angiotensin I to produce angiotensin II, which is a potent vasoconstrictor that prevents the catalytic function of bradykinin, a vasodilator. Recent research has shown that inhibition of ACE with food derived peptides could be an effective way in the prevention/management of hypertension. It has been demonstrated that numerous peptides isolated from various food sources (milk, egg, fish, meat, marine organisms and vegetables) have shown anti-hypertensive activity [49-57].

Recently, several researchers investigated the anti-hypertensive effects of peptides derived from peanut worms such as Phascolosoma esculenta and Sipunculus nudus. Antihypertensive activities of peptides originated from peanut worms have been widely studied due to their excellent bioactive properties and safety profiles. Pepsin and trypsin are the two proteolytic enzymes that are extensively used in the production of anti-hypertensive peptides from peanut worms [3,17,58-61]. These enzymes specifically cleave the large molecular weight proteins into smaller peptides. The large proteins are usually unable to bind the active site of ACE, however, the smaller peptides generated by enzymatic hydrolysis could easily bind to the active site of ACE as inhibitor and thereby prevent high blood pressure [3]. It has been demonstrated that peptides derived from peanut worms showed anti-hypertensive activity through several mechanisms including changing the secondary structure of ACE, competitive and non-competitive inhibition of ACE, reducing systolic blood pressure and binding to the active sites of ACE [17,58-60] (Table 5). 
Table 5. Molecular mechanisms of action of ACE-inhibitory/anti-hypertensive peptides derived from various peanut worms.

\begin{tabular}{|c|c|c|c|c|c|c|}
\hline Peanut Worm Name & $\begin{array}{l}\text { Enzyme Employed to } \\
\text { Produce Peptides }\end{array}$ & $\begin{array}{l}\text { Peptide Sequence and } \\
\text { Molecular Weight }\end{array}$ & $\begin{array}{l}\text { In Vitro/Cell Culture/ } \\
\text { Animals/Humans Used } \\
\text { for the Study }\end{array}$ & $\begin{array}{l}\mathrm{IC}_{50} / \mathrm{EC}_{50} \\
\text { Values }\end{array}$ & Activity/Mechanisms of Action Showed & Ref. \\
\hline Phascolosoma esculenta & Pepsin & AWLHPGAPKVF & $\begin{array}{l}\text { In vitro ACE inhibition } \\
\text { assay \& spontaneously } \\
\text { hypertensive rats }\end{array}$ & $\mathrm{IC}_{50}$ value of $135 \mathrm{M}$ & $\begin{array}{l}\text { Peptide inhibited ACE through competitive } \\
\text { inhibition and exhibited anti-hypertensive } \\
\text { effects in rats by significantly reducing the } \\
\text { systolic blood pressure around } 30 \mathrm{mmHg} \text {. }\end{array}$ & [60] \\
\hline Phascolosoma esculenta & Pepsin and trypsin & $\longrightarrow$ & $\begin{array}{l}\text { In vitro ACE inhibition } \\
\text { assay \& spontaneously } \\
\text { hypertensive rats }\end{array}$ & $\begin{array}{c}\mathrm{IC}_{50} \text { values of } 0.67 \text { and } \\
0.24 \mathrm{mg} / \mathrm{mL}\end{array}$ & $\begin{array}{l}\text { Peptides significantly reduced both diastolic } \\
\text { blood pressure (DBP) and systolic blood } \\
\text { pressure (SBP) and inhibited ACE in vitro. }\end{array}$ & [3] \\
\hline Phascolosoma esculenta & Pepsin, and trypsin & $\begin{array}{c}\text { AYF, EL, GLR, HK, and } \\
\text { ILK }\end{array}$ & $\begin{array}{c}\text { In vitro ACE inhibition } \\
\text { assay }\end{array}$ & $\begin{array}{l}\mathrm{IC}_{50} \text { values of } \\
3.43-4.18 \mathrm{U} / \mathrm{ml}\end{array}$ & $\begin{array}{l}\text { Peptides exhibited ACE inhibitory activity } \\
\text { with } \mathrm{IC}_{50} \text { values in the range of } \\
3.43-4.18 \mathrm{U} / \mathrm{mL}\end{array}$ & [61] \\
\hline Phascolosoma esculenta & Pepsin and trypsin & 284 di- and tri-peptides & $\begin{array}{c}\text { In vitro ACE inhibition } \\
\text { assay }\end{array}$ & $\mathrm{IC}_{50}$ less than $50 \mu \mathrm{M}$ & Peptides inhibited the ACE. & [58] \\
\hline Sipunculus nudus & Protamex & IND, VEPG, LADEF & $\begin{array}{l}\text { In vitro ACE inhibition } \\
\text { assay }\end{array}$ & $\begin{array}{c}\mathrm{IC}_{50} \text { values for } \mathrm{ACE} \\
\text { inhibition were } 34.72, \\
20.55 \text { and } 22.77 \mu \mathrm{mol} / \mathrm{L}\end{array}$ & $\begin{array}{c}\text { The peptides IND, VEPG, and LADEF } \\
\text { showed ACE inhibition activity with } \mathrm{IC}_{50} \\
\text { values of } 34.72,20.55 \text { and } 22.77 \mu \mathrm{mol} / \mathrm{L}, \\
\text { respectively. }\end{array}$ & [62] \\
\hline Phascolosoma esculenta & Pepsin and trypsin & $\begin{array}{l}\text { RYDF, YASGR and } \\
\text { GNGSGYVSR }\end{array}$ & $\begin{array}{l}\text { In vitro ACE inhibition } \\
\text { assay \& spontaneously } \\
\text { hypertensive rats }\end{array}$ & $\begin{array}{c}\mathrm{IC}_{50} \text { values of } 235,184 \text { and } \\
29 \mu \mathrm{M} \text { respectively for } \\
\text { RYDF, YASGR and } \\
\text { GNGSGYVSR }\end{array}$ & $\begin{array}{l}\text { Three peptides inhibited ACE through } \\
\text { non-competitive inhibition. GNGSGYVSR } \\
\text { reduced systolic blood pressure } 31 \mathrm{mmHg} \text { at } \\
2 \mathrm{~h} \text { after oral administration in spontaneously } \\
\text { hypertensive rats. }\end{array}$ & [59] \\
\hline Phascolosoma esculenta & Pepsin and trypsin & GNGSGYV and SR & $\begin{array}{l}\text { In vitro ACE inhibition } \\
\text { assay }\end{array}$ & $\mathrm{IC}_{50}$ value of $170 \mu \mathrm{M}$ & $\begin{array}{l}\text { GNGSGYV and SR showed ACE inhibition } \\
\text { through synergistic effect. SR initially } \\
\text { attacked the catalytic Zn of ACE and formed } \\
\text { coordinate bond, and then GNGSGYV } \\
\text { attached with the residues of ACE active site } \\
\text { by hydrogen bonds. }\end{array}$ & [17] \\
\hline
\end{tabular}


The ACE inhibitory/antihypertensive activity of food derived peptides depends on the composition, sequence and length of the peptides. Peptides with more hydrophobic amino acids (aromatic and branched chain aliphatic) have been demonstrated to inhibit ACE efficiently [3]. Most of the ACE inhibitory peptides isolated from peanut worms contain 2-11 amino acids residues [17,58-60,62]. Du et al. [60] used pepsin to cleave the water soluble protein of Phascolosoma esculenta in order to obtain low molecular weight peptides with potent angiotensin I-converting enzyme (ACE) inhibitory activity. A novel ACE inhibitory peptide, Ala-Trp-Leu-His-Pro-Gly-Ala-Pro-Lys-Val-Phe, was isolated with $\mathrm{IC}_{50}$ value of $135 \mathrm{M}$. The authors investigated the inhibitory kinetics of the peptide and found that the identified peptide inhibited ACE through competitive inhibition. Furthermore, the peptide (Ala-Trp-Leu-His-Pro-Gly-Ala-Pro-Lys-Val-Phe) at $10 \mathrm{mg} / \mathrm{kg}$ dose showed antihypertensive effects in spontaneously hypertensive rats (SHR) by significantly decreasing the systolic blood pressure (SBP) around $30 \mathrm{mmHg}$. Water-soluble and insoluble proteins of P. esculenta were extracted, by Wu et al. [3], and the fractions hydrolyzed with pepsin and trypsin. The hydrolysates exhibited ACE inhibitory activity with $\mathrm{IC}_{50}$ values between 0.1 to $0.67 \mathrm{mg} / \mathrm{mL}$. It was demonstrated that the peptides derived from water-soluble and insoluble proteins significantly reduced both diastolic blood pressure (DBP) (23-45 $\mathrm{mmHg}$ ) and systolic blood pressure (SBP) (20-33 mmHg) in spontaneously hypertensive rats after single oral administration at a dose of $1 \mathrm{~g} / \mathrm{kgBW}$. Protein from Sipunculus nudus was hydrolysed with Protamex and three ACE inhibitory peptides IND, VEPG, and LADEF were isolated with $\mathrm{IC}_{50}$ values of $34.72,20.55$ and $22.77 \mu \mathrm{mol} / \mathrm{L}$, respectively [62]. In another investigation, Guo et al. [59] identified and isolated three anti-hypertensive peptides, RYDF, YASGR and GNGSGYVSR, from Phascolosoma esculenta. It was found that the three peptides inhibited ACE through non-competitive inhibition with $\mathrm{IC}_{50}$ values between 29-235 $\mu \mathrm{M}$. Furthermore, GNGSGYVSR reduced systolic blood pressure by $31 \mathrm{mmHg}$ at $2 \mathrm{~h}$ after oral administration in spontaneously hypertensive rats. Recently, two novel ACE inhibitory peptides, GNGSGYV and SR, were reported from Phascolosoma esculenta after hydrolysis with pepsin and trypsin. The two peptides showed synergistic effect on ACE inhibition with $\mathrm{IC}_{50}$ value of $170 \mu \mathrm{M}$. The synergistic mechanism indicated that SR and GNGSGYV significantly changed the secondary structure of ACE. It was also found that the peptide SR initially formed a coordinate bond with the catalytic Zn of ACE and then GNGSGYV attached with arginine of dipeptide (SR) and the amino acids of ACE active site through hydrogen bonds and thereby prevent the substrate attachment with ACE [17]. In addition to the traditional hydrolysis, virtual hydrolysis of peanut worms has been performed by several researchers in order to identify the potential ACE inhibitory peptides. Hongxi et al. [61] virtually hydrolyzed Phascolosoma esculenta protein with pepsin and trypsin and identified five ACE inhibitory peptides, AYF, EL, GLR, HK and ILK, with $\mathrm{IC}_{50}$ values in the range of 3.43-4.18 U/mL. In another study, Liu et al. [58] conducted virtual hydrolysis of Phascolosoma esculenta with pepsin, trypsin and a mixture of pepsin and trypsin for identification of ACE inhibitory peptides and predicted that 284 di- and tri-peptides from Phascolosoma esculenta possess ACE inhibitory activity with $\mathrm{IC}_{50}$ less than $50 \mu \mathrm{M}$.

The research indicates that anti-hypertensive peptides obtained from peanut worms could be used as a natural component for application in health foods/nutraceuticals to prevent/treat hypertension. However, further research is needed on the exact molecular mechanisms of action of these anti-hypertensive peptides.

\section{Immunomodulatory Activity of Polysaccharides Derived from Peanut Worms}

Immune system is a complex defense network that protects the body against invading pathogens such as bacteria, viruses, fungi, protozoans, and prevents the growth of cancer cells. Immunomodulators are compounds that can potentially suppress or stimulate the immune system of host by modulating various immune cells and/or their signaling molecules (e.g., T cells, B cells, macrophages, NK cells, dendritic cells and cytokines) [63]. 
Recently, several polysaccharides with immunomodulatory activity have been identified from various food sources including mushrooms, fruits, cereals and algae [13].

Recent research has indicated that polysaccharides stimulate various immune cells (e.g., macrophages, NK cells, dendritic cells) by binding to the cell surface receptors such as Toll-like receptor 4 (TLR4), cluster of differentiation 14 (CD14), scavenger receptor (SR), complement receptor 3 (CR3), mannose receptor (MR) and Dectin-1 [13,63].

It has been demonstrated that polysaccharides derived from peanut worms exert immunomodulatory effects through various mechanisms such as activation of macrophages, increasing the indexes of immune organs (thymus and spleen), enhancing the secretion of cytokines, and improving the phagocytosis function of macrophages and NK cell activity $[18,64-66]$. Table 6 shows the immunomodulatory activities of polysaccharides derived from peanut worms.

A number of studies reported the immune stimulating activity of polysaccharides extracted from peanut worms, Sipunculus nudus and Phascolosoma esculenta. Liang et al. [64] investigated the immunomodulatory effects of polysaccharides from P. esulenta using a mice model and found that administration of polysaccharides at 3.0, 6.0, 9.0 mg/kgBW for 2 months considerably stimulated the Con-A activated mouse spleenocytes and increased the index of liver, spleen and thymus of mice. A water soluble polysaccharide, composed of rhamnose (28\%), fucose (16\%) and galactose (56\%), extracted from Sipunculus nudus exhibited immunomodulatory effects by activating macrophages through the upregulation of expression of cytokines, IL- 6 and TNF- $\alpha$, and inducing the expression of iNOS and COX-2 [65]. Li et al. [66] reported that polysaccharides from Sipunculus nudus enhanced the cellular and humoral immunity in mice by increasing the phagocytosis function and NK cell activity. Su et al. [67] used hepatoma (HepG2) bearing mice model to study the immunomodulatory effects of polysaccharides derived from Sipunculus nudus. The mice were treated with 50,100 , and $200 \mathrm{mg} / \mathrm{kg}$ polysaccharide for 30 days and it was found that the polysaccharide composed of L-rhamnose, L-arabinose, D-ribose, D-glucose and D-galactose showed immune stimulating effects through increase of thymus and spleen indexes, and upregulated the IL-2, IFN- $\gamma$, and TNF- $\alpha$ cytokines in serum of mice. In another recent study, Su et al. [18] demonstrated that polysaccharide of Sipunculus nudus increased the index of immune organs and augmented the secretion of cytokines, IL-2, IFN- $\gamma$ and TNF- $\alpha$, in hepatoma mice after treatment with 50,100 and $200 \mathrm{mg} / \mathrm{kg}$ polysaccharides for 16 days. These results suggest that immunomodulatory polysaccharides from peanut worms have great potential for application as nutraceutical/health foods.

Although immunomodulatory activities of polysaccharides derived from peanut worms have been documented, the molecular mechanisms of action and structure-function relationship of these polysaccharides have not been investigated. Thus, more research is needed on molecular mechanisms to decipher the immunomodulatory effects of these polysaccharides. Additionally, the immune stimulatory effects of peptides derived peanut worms need to be investigated considerably in order to enhance their application as health foods. 
Table 6. Molecular mechanisms of immunomodulatory activity of polysaccharides derived from peanut worms.

\begin{tabular}{|c|c|c|c|c|c|}
\hline Source & Composition of Polysaccharide Extract & $\begin{array}{l}\text { Cell Culture/ } \\
\text { Animal Models }\end{array}$ & Dose and Duration & Molecular Mechanisms/Effects & Ref. \\
\hline Phascolosoma esculenta & $\longrightarrow$ & Mice model & $\begin{array}{c}3.0,6.0,9.0 \mathrm{mg} / \mathrm{kgBW} \text { for } \\
2 \text { months }\end{array}$ & $\begin{array}{l}\text { Polysaccharides from P. esulenta significantly } \\
\text { enhanced liver, spleen and thymus index of mice } \\
\text { and increased Con A-stimulated mouse spleen cells. }\end{array}$ & [64] \\
\hline Sipunculus nudus & $\begin{array}{l}\text { Monosaccharide composition -rhamnose } \\
(28 \%) \text {, fucose }(16 \%) \text { and galactose }(56 \%)\end{array}$ & $\begin{array}{l}\text { Murine macrophages from } \\
\text { BALB/c mice and human } \\
\text { macrophages }\end{array}$ & $5-80 \mu \mathrm{g} / \mathrm{mL}$ for $24 \mathrm{~h}$ & $\begin{array}{l}\text { The water soluble polysaccharide isolated from } \\
\text { S. nudus showed immunostimulating activity by } \\
\text { activating macrophages through the upregulation } \\
\text { of expression of cytokines, IL- } 6 \text { and TNF- } \alpha \text {, and } \\
\text { inducing the expression of iNOS and COX- } 2 \text {. }\end{array}$ & [65] \\
\hline Sipunculus nudus & - & Mice & - & $\begin{array}{l}\text { Polysaccharides from Sipunculus nudus promoted } \\
\text { the cellular immunity and humoral immunity } \\
\text { through the enhancing the phagocytosis function } \\
\text { and NK cell activity in mice. }\end{array}$ & [66] \\
\hline Sipunculus nudus & $\begin{array}{l}\text { L-rhamnose, Larabinose, D-ribose, } \\
\text { D-glucose and D-galactose }\end{array}$ & $\begin{array}{c}\text { Hepatoma HepG2-bearing } \\
\text { Mice }\end{array}$ & $\begin{array}{l}50,100, \text { and } 200 \mathrm{mg} / \mathrm{kg} \\
1 \mathrm{month}\end{array}$ & $\begin{array}{l}\text { Polysaccharide extract from Sipunculus nudus } \\
\text { enhanced the immune response through increase of } \\
\text { thymus and spleen indexes, and upregulating the } \\
\text { IL-2, IFN- } \gamma \text {, and TNF- } \alpha \text { cytokines in serum of mice. }\end{array}$ & [67] \\
\hline
\end{tabular}




\section{Anti-Cancer Activities of Polysaccharides Derived from Peanut Worms}

Cancer is one of the major causes of death worldwide. Approximately 10 million deaths were occurred in 2020 due to various cancers [68]. Cancer is uncontrolled growth of cells in the body. The cancer cells attack the adjacent normal cells and spread to the other parts of the body. Currently, many different chemo drugs are used in the cancer treatment. However, side effects (neutropenia, nausea, vomiting, hair loss, blood clots etc.) associated with these drugs have limited their usage. Additionally, several chemotherapy drugs kill the normal cells along with the cancer cells. Therefore, recently there is great interest in finding new anti-cancer agents with less side effects from natural sources such as spices, vegetables, marine sources etc. [69,70]. Polysaccharides isolated from numerous natural resources including plant and marine sources have been reported to have inhibition activity on malignant cells primarily through the induction of apoptosis [71,72].

Polysaccharides extracted from peanut worms have been demonstrated to possess anticancer activity against cancer cells and in vivo animal models. Most researchers determined the anti-cancer effects of peanut worm derived polysaccharides in hepatocellular carcinoma. Scientific evidence from recent studies showed that polysaccharides derived from peanut worms exhibited anti-cancer effects by modulating numerous molecular mechanisms including preventing the DNA synthesis, increasing the expression of pro-apoptosis proteins, TNF- $\alpha$, caspase-3, and Bax, decreasing the expression of the anti-apoptosis proteins, survivin, Bcl-2, and VEGF, up-regulation of caspase-3, caspase-8, and caspase-9, enhancing the expression of ATF4, DDIT3, and IkB $\alpha$ and reduction of CYR61, HSP90, and VEGF expression $[18,67,73]$. The mechanisms of action of anticancer activities of polysaccharides derived from peanut worms are presented in Table 7.

Polysaccharides isolated from peanut worm Sipunculus nudus have shown anti-cancer effects in cultured cancer cells and mice models with transplanted cancer cells. Jie et al. [73,74] studied the molecular mechanisms of anticancer effects of polysaccharides, extracted from Sipunculus nudus, after treating the Hepg2.2.15 cells with $0.13,0.25,0.5$ and $1 \mathrm{mg} / \mathrm{mL}$ for 24 and $48 \mathrm{~h}$ and reported that Sipunculus nudus derived polysaccharides induced dosedependent apoptosis on Hepg2.2.15 cells by increasing the expression of pro-apoptosis proteins, TNF- $\alpha$, caspase- 3 , and Bax, and decreasing the expression of the anti-apoptosis proteins, survivin, Bcl-2, and VEGF. Su et al. [67] investigated the anti-cancer effects of polysaccharides of Sipunculus nudus using HepG2 cells-bearing mice model and demonstrated that administration of polysaccharides at 50, 100 and $200 \mathrm{mg} / \mathrm{kg}$ for 1 month significantly inhibited the growth of HepG2 cells through increasing the expression of ATF4, DDIT3 and IkB $\alpha$ and down-regulation of CYR61, HSP90 and VEGF expression. In another recent study, Su et al. [18] reported that polysaccharides extracted from Sipunculus nudus showed anti-cancer effects in HepG2-bearing mice by inducing the apoptosis of tumor cells through the up-regulation of caspase-3, caspase-8, caspase-9 and Bax, and down-regulation of B-cell lymphoma-2 and vascular endothelial growth factor protein expression.

The above scientific evidence confirmed that polysaccharides of peanut worms could inhibit the growth of the cancer cells. However, there are various limitations that could hamper the use of these polysaccharides for human applications as nutraceuticals/drugs. Firstly, more reliable and consistent scientific evidence from clinical studies about the beneficial effects of these polysaccharides is needed before its use for the treatment/management of cancer. Secondly, data about cytotoxic effects on normal cells and in-depth knowledge of exact molecular mechanisms of anti-cancer activity of peanut worms derived polysaccharides are required from cell culture, animal and clinical studies. Additionally, most studies investigated the anticancer activity of polysaccharides isolated from Sipunculus $n u d u s$, although there are many peanut worm species in phylum, Sipuncula. Therefore, anti-cancer activity for polysaccharides of other peanut worm species needs to be explored. 
Table 7. Molecular mechanisms of anti-cancer activity of polysaccharides derived from various peanut worms.

\begin{tabular}{|c|c|c|c|c|c|}
\hline Source & $\begin{array}{c}\text { Composition of } \\
\text { Polysaccharide Extract }\end{array}$ & $\begin{array}{l}\text { Cell Culture/ } \\
\text { AnimalModels }\end{array}$ & $\begin{array}{l}\text { Dose and } \\
\text { Duration }\end{array}$ & Molecular Mechanisms/Effects & Ref. \\
\hline $\begin{array}{l}\text { Sipunculus } \\
\text { nudus }\end{array}$ & $\begin{array}{c}\text { Extractcontains } 35.3 \% \text { neutral } \\
\text { sugar, including Ara } 10.7 \% \text {, } \\
\text { Rha } 12.6 \% \text {, Gal } 16.4 \% \text {, Glu } \\
31.3 \% \text {, Xyl } 18.2 \% \text {, and } \\
\text { Man } 10.8 \% .\end{array}$ & Hepg2.2.15 cells & $\begin{array}{l}0.13,0.25,0.5 \\
\text { and } \\
1 \mathrm{mg} / \mathrm{mL} \text { for } \\
24 \text { and } 48 \mathrm{~h}\end{array}$ & $\begin{array}{l}\text { Polysaccharides showed anti-cancer } \\
\text { activities by preventing the DNA } \\
\text { synthesis of Hepg2.2.15 cells and } \\
\text { increasing the expression of } \\
\text { pro-apoptosis proteins, TNF- } \alpha \text {, } \\
\text { caspase-3, and Bax, and decreasing the } \\
\text { expression of the anti-apoptosis } \\
\text { proteins survivin, Bcl-2, and VEGF. }\end{array}$ & [73] \\
\hline $\begin{array}{l}\text { Sipunculus } \\
\text { nudus }\end{array}$ & $\begin{array}{c}\text { L-rhamnose, Larabinose, } \\
\text { D-ribose, D-glucose and } \\
\text { D-galactose }\end{array}$ & $\begin{array}{c}\text { Hepatoma } \\
\text { HepG2-bearing } \\
\text { Mice }\end{array}$ & $\begin{array}{l}50,100, \text { and } \\
200 \mathrm{mg} / \mathrm{kg}, \\
1 \text { month }\end{array}$ & $\begin{array}{l}\text { Polysaccharides showed anti-tumor } \\
\text { activity by inhibiting the growth of } \\
\text { HepG2 cells through increase of ATF4, } \\
\text { DDIT3, and IkB } \alpha \text { expression and } \\
\text { decrease of CYR61, HSP90, and } \\
\text { VEGF expression. }\end{array}$ & [67] \\
\hline $\begin{array}{l}\text { Sipunculus } \\
\text { nudus }\end{array}$ & $\begin{array}{c}\text { Repeating units of } \\
\rightarrow 3,4-\beta \text {-D-GlcpNAC } \\
(1 \rightarrow \text { and } \rightarrow 4)-\alpha \text {-D-Glcp }(1 \rightarrow \\
\text { in the ratio of } 15: 1 ; \\
\rightarrow 2)-\alpha \text {-D-Galp- }(1 \rightarrow \text { as a side } \\
\text { chain; and } \beta \text {-D-Galp- }(1 \rightarrow \text { and } \\
\alpha \text {-D-Glcp- }(1 \rightarrow \text { as end groups }\end{array}$ & $\begin{array}{c}\text { hepatoma } \\
\text { HepG2-bearing } \\
\text { mice }\end{array}$ & $\begin{array}{l}50,100, \text { and } \\
200 \mathrm{mg} / \mathrm{kg} \\
16 \text { days }\end{array}$ & $\begin{array}{l}\text { Extracted polysaccharide enhanced the } \\
\text { apoptosis of tumour cells through the } \\
\text { mitochondrial apoptosis pathway by } \\
\text { upregulating caspase- } 3 \text {, caspase- } 8 \text {, } \\
\text { caspase- } 9 \text { and BCL2-associated X, and } \\
\text { downregulating B-cell lymphoma- } 2 \\
\text { and vascular endothelial growth factor } \\
\text { protein expression. }\end{array}$ & [18] \\
\hline
\end{tabular}

\section{Other Bioactivities of Peanut Worm Derived Peptides and Polysaccharides}

Apart from above mentioned bioactive properties, many researchers documented various other bioactive properties including wound healing capacity, memory improvement and anti-hypoxia activity for peanut worm derived peptides and polysaccharides (Tables 8 and 9). Chen-Xiao and $\mathrm{Zi}-\mathrm{Ru}$ [14] used various hypoxia mice models to determine the anti-hypoxia activity of polysaccharides extracted from Sipunculus nudus and revealed that polysaccharides showed significant anti-hypoxic activity on normobaric hypoxia, chemical intoxicant hypoxia and acute cerebral ischemia hypoxia models after treatment with 10, 30, $100 \mathrm{mg} / \mathrm{kg}$ for 6 days. Liu et al. [15] produced peptides $<3 \mathrm{kDa}$ from Phascolosoma esculenta by using pancreatin and found that administration of peptides at 50, 100 and $150 \mathrm{mg} / \mathrm{kg}$ for 15 days improved the spatial learning and memory ability in mice through the up-regulation of NR2A, NR2B, BDNF and CREB mRNA expressions in hippocampus. Lin et al. [20] investigated the wound healing properties of collagen peptides derived from Sipunculus nudus and demonstrated that the peptides clearly improved the healing rate and inhibited scar formation in mice by enhancing collagen deposition and inhibition of TGF- $\beta /$ Smads signaling pathway.

Table 8. Anti-hypoxia activity of polysaccharides derived from various peanut worms.

\begin{tabular}{ccccc}
\hline Source & $\begin{array}{c}\text { Composition of } \\
\text { Polysaccharide Extract }\end{array}$ & $\begin{array}{c}\text { Cell Culture/ } \\
\text { Animal Models }\end{array}$ & $\begin{array}{c}\text { Dose and } \\
\text { Duration }\end{array}$ & Molecular Mechanisms/Effects \\
\hline Sipunculus nudus & $\begin{array}{c}\text { Rhamnose (28\%), } \\
\text { fucose (16\%) and } \\
\text { galactose (56\%). }\end{array}$ & Mice model & $\begin{array}{c}\text { The extracted polysaccharide } \\
100 \mathrm{mg} / \mathrm{kg} \\
\text { for } 6 \text { days }\end{array}$ & $\begin{array}{c}\text { exhibited significant anti-hypoxic } \\
\text { activity on normobarie hypoxia, } \\
\text { chemical intoxicant hypoxia and } \\
\text { acute cerebral ischemia hypoxia } \\
\text { models in mice. }\end{array}$ \\
\hline
\end{tabular}


Table 9. Effects of peptides derived from peanut worms on wound healing and spatial learning and memory.

\begin{tabular}{|c|c|c|c|c|c|c|}
\hline $\begin{array}{l}\text { Peanut } \\
\text { Worm } \\
\text { Name }\end{array}$ & $\begin{array}{l}\text { Enzyme Used } \\
\text { to Produce } \\
\text { Peptides }\end{array}$ & $\begin{array}{l}\text { Peptide } \\
\text { Sequence and } \\
\text { Molecular } \\
\text { Weight }\end{array}$ & $\begin{array}{l}\text { In Vitro/Cell Culture/ } \\
\text { Animals/Humans } \\
\text { Used for the Study }\end{array}$ & $\begin{array}{l}\text { Dose and } \\
\text { Duration }\end{array}$ & $\begin{array}{c}\text { Mechanism of Action/ } \\
\text { Activities/Effects Showed }\end{array}$ & Ref. \\
\hline $\begin{array}{l}\text { Sipunculus } \\
\text { nudus }\end{array}$ & $\begin{array}{c}\text { Animal } \\
\text { hydrolytic } \\
\text { protease } \\
(3000 \mathrm{U} / \mathrm{g}) \text { and } \\
\text { flavor protease } \\
(3000 \mathrm{U} / \mathrm{g})\end{array}$ & $\begin{array}{l}\text { Collagen pep- } \\
\text { tides }<5 \mathrm{kDa}\end{array}$ & $\begin{array}{l}\text { human umbilical } \\
\text { vein endothelial cells } \\
\text { (HUVEC), human } \\
\text { immortalized } \\
\text { keratinocytes } \\
\text { (HaCaT) and human } \\
\text { skin fibroblasts (HSF) } \\
\text { and mice }\end{array}$ & $\begin{array}{c}2 \mathrm{~g} / \mathrm{mL} \text { for } \\
28 \text { days and } \\
500 \mu \mathrm{g} / \mathrm{mL} \text { for } \\
12,24,30,36 \mathrm{~h}\end{array}$ & $\begin{array}{l}\text { Collagen peptides derived } \\
\text { from Sipunculus nudus } \\
\text { exhibited great capacity to } \\
\text { induce HUVEC, HaCaT } \\
\text { and HSF cells proliferation } \\
\text { and migration in vitro. } \\
\text { Peptides noticeably } \\
\text { improved the healing rate } \\
\text { and inhibited scar } \\
\text { formation in mice through } \\
\text { the mechanisms of } \\
\text { reducing inflammation, } \\
\text { enhancing collagen } \\
\text { deposition and } \\
\text { recombination and } \\
\text { blockade of the } \\
\text { TGF- } \beta / \text { Smads signal } \\
\text { pathway. }\end{array}$ & [20] \\
\hline $\begin{array}{l}\text { Phascolosoma } \\
\text { esculenta }\end{array}$ & Pancreatin & Peptides $<3 \mathrm{kDa}$ & Mice & $\begin{array}{c}50,100 \text { and } \\
150 \mathrm{mg} / \mathrm{kg} \text { for } \\
15 \text { days }\end{array}$ & $\begin{array}{l}\text { Peptides improved the } \\
\text { spatial learning and } \\
\text { memory ability } \\
\text { doses-dependently } \\
\text { through the up-regulation } \\
\text { of NR2A, NR2B, BDNF } \\
\text { and CREB mRNA } \\
\text { expressions in } \\
\text { hippocampus of mice. } \\
100 \text { mg/kg group showed } \\
\text { better performance in } \\
\text { spatial learning and } \\
\text { memory compared with } \\
50 \text {, and } 150 \mathrm{mg} / \mathrm{kg} .\end{array}$ & [15] \\
\hline
\end{tabular}

\section{Conclusions}

In this review, the various bioactive properties of peptides and polysaccharides originated from peanut worms were summarized. Peanut worms derived bioactive compounds (peptides and polysaccharides) exhibited anti-oxidant, anti-inflammatory, immunomodulatory, anti-hypertensive, anti-cancer and wound healing activities through the modulation of various molecular mechanisms. Most researchers investigated these bioactivities using in vitro, cell culture and animal models. Clinical studies confirming these bioactivities of peptides and polysaccharides of peanut worms are scanty in literature. Therefore, more clinical investigations are needed to enhance the applications of these bioactive compounds of peanut worms. Additionally, in-depth molecular mechanisms of action, bioavailability and safety profiles of these bioactive compounds of peanut worms need to be investigated thoroughly. Moreover, peptides produced from peanut worms could be further explored for their potential anti-diabetic, anti-microbial, anti-obesity and anti-atherosclerosis activities. Although there are several species in phylum sipuncula, only two species (Sipunculus nudus and Phascolosoma esculenta) have been investigated extensively with regard to the bioactive compound's identification and isolation. Hence, other species of peanut worms could also be studied for possible identification of bioactive compounds for various human applications. 
Author Contributions: Y.Q. and J.Z. prepared the original draft, X.S., S.L. and M.C. collected and analyzed the data, H.L. and L.C. revised manuscript and supervised the work. All authors have read and agreed to the published version of the manuscript.

Funding: This research was funded by the public service platform of South China Sea for R \& D marine biomedicine resources (2017C8A), Zhanjiang Science and Technology Development Special Fund Project 2020A04005 and Guangdong province science and technology plan project (2HC19002).

Institutional Review Board Statement: Not applicable.

Data Availability Statement: Not applicable.

Conflicts of Interest: The authors declare no conflict of interest.

\begin{abstract}
Abbreviations
ACE: Angiotensin I-converting enzyme; ATF4: Activating transcription factor 4; Bcl-2: B-cell lymphoma 2; BDNF: Brain Derived Neurotrophic Factor; CD14: cluster of differentiation 14; COX-2: cyclooxygenase-2; CR3: complement receptor 3; CREB: cAMP responsive element binding protein; CYR61: Cysteine-rich angiogenic inducer 61; DBP: diastolic blood pressure; DDIT3:DNA Damage Inducible Transcript 3; DNA: Deoxyribonucleic acid; DPPH: 2,2-diphenyl-1-picrylhydrazyl; GPx: Glutathione peroxidase; GSH-Px: glutathione peroxidase; HaCaT: human immortalized keratinocytes; HSF: human skin fibroblasts; HSP90: Heat shock protein 90; HUVEC: human umbilical vein endothelial cells; IFN- $\gamma$ : Interferon gamma; IL: interleukin; iNOS: inducible nitric oxide synthase; MDA: malondialdehyde; mRNA: messenger ribonucleic acid; MR: mannose receptor; NF- $\mathrm{kB}$ : nuclear factor kappa B; NK cells: Natural killer cells; NO: Nitric oxide; Nrf2: nuclear factor erythroid 2-related factor; NSAIDs: non-steroidal anti-inflammatory drugs; ROS: reactive oxygen species; SBP: systolic blood pressure; SR: scavenger receptor; SOD: superoxide dismutase; TAC: Totalantioxidantcapacity; TGF- $\beta 1$ : Transforming growth factor beta1; TLR4: Toll-like receptor 4; TNF- $\alpha$ : Tumour Necrosis Factor alpha; VEGF: Vascular endothelial growth factor.
\end{abstract}

\title{
References
}

1. Sangtanoo, P.; Srimongkol, P.; Saisavoey, T.; Reamtong, O.; Karnchanatat, A. Anti-inflammatory action of two novel peptides derived from peanut worms (Sipunculus nudus) in lipopolysaccharide-induced RAW264.7 macrophages. Food Funct. 2020, 11, 552-560. [CrossRef] [PubMed]

2. Zhang, C.X.; Dai, Z.R.; Cai, Q.X. Anti-inflammatory and anti-nociceptive activities of Sipunculus nudus L. extract. J. Ethnopharmacol. 2011, 137, 1177-1182. [CrossRef] [PubMed]

3. Wu, Y.; Fang, M.; Du, L.; Wu, H.; Liu, Y.; Guo, M.; Xie, J.; Wei, D. The nutritional composition and anti-hypertensive activity on spontaneously hypertensive rats of sipuncula Phascolosoma esculenta. Food Funct. 2014, 5, 2317. [CrossRef] [PubMed]

4. Ruiz-Ruiz, F.; Mancera-Andrade, E.I.; Iqbal, H.M. Marine-Derived Bioactive Peptides for Biomedical Sectors: A Review. Protein Pep. Lett. 2017, 24, 109-117. [CrossRef]

5. Lee, Y.E.; Kim, H.; Seo, C.; Park, T.; Lee, K.B.; Yoo, S.Y.; Hong, S.C.; Kim, J.T.; Lee, J. Marine polysaccharides: Therapeutic efficacy and biomedical applications. Arch. Pharm. Res. 2017, 40, 1006-1020. [CrossRef] [PubMed]

6. Zhong, Q.; Wei, B.; Wang, S.; Ke, S.; Chen, J.; Zhang, H.; Wang, H. The Antioxidant Activity of Polysaccharides Derived from Marine Organisms: An Overview. Mar. Drugs 2019, 17, 674. [CrossRef]

7. Chalamaiah, M.; Yu, W.; Wu, J. Immunomodulatory and anticancer protein hydrolysates (peptides) from food proteins: A review. Food Chem. 2018, 245, 205-222. [CrossRef]

8. Chalamaiah, M.; Ulug, S.K.; Hong, H.; Wu, J. Regulatory requirements of bioactive peptides (protein hydrolysates) from food proteins. J. Funct. Foods 2019, 58, 123-129. [CrossRef]

9. Pádraigín, A.H.; Richard, J.G. Bioactive peptides from marine processing waste and shellfish: A review. J. Funct. Foods 2012, 4, 6-24.

10. Wang, X.; Yu, H.; Xing, R.; Li, P. Characterization, preparation, and purification of marine bioactive peptides. BioMed Res. Int. 2017, 2017, 9746720. [CrossRef]

11. Yu, Y.; Shen, M.; Song, Q.; Xie, J. Biological activities and pharmaceutical applications of polysaccharide from natural resources: A review. Carbohydr. Polym. 2018, 183, 91-101. [CrossRef] [PubMed]

12. Jun, L.; Stefan, W.; Chunlin, X. A review of bioactive plant polysaccharides: Biological activities, functionalization, and biomedical applications. Bioact. Carbohydr. Diet. Fibre 2015, 5, 31-61.

13. Barbosa, J.R.; de Carvalho Junior, R.N. Polysaccharides obtained from natural edible sources and their role in modulating the immune system: Biologically active potential that can be exploited against COVID-19. Trends Food Sci. Technol. 2021, 108, 223-235. [CrossRef] [PubMed] 
14. Zhang, C.X.; Dai, Z.R. Anti-hypoxia activity of a polysaccharide extracted from the Sipunculus nudus L. Int. J. Biol. Macromol. 2011, 49, 523-526. [CrossRef] [PubMed]

15. Liu, L.; Cao, J.; Chen, J.; Zhang, X.; Wu, Z.; Xiang, H. Effects of peptides from Phascolosoma esculenta on spatial learning and memory via anti-oxidative character in mice. Neurosci. Lett. 2016, 631, 30-35. [CrossRef]

16. Yang, Z.; Pan, Y.; Chen, J.; Zhang, H.; Wei, H.; Wu, Z.; Liu, L. Anti-inflammatory, anti-oxidative stress effect of Phascolosoma esculenta oligosaccharides on Escherichia coli-induced sepsis mice. Food Sci. Biotechnol. 2019, 28, 1871-1879. [CrossRef]

17. Wu, J.; Xie, D.; Chen, X.; Tang, Y.J.; Wang, L.; Xie, J.; Wei, D. Inhibitory mechanism of a substrate-type angiotensin I-converting enzyme inhibitory peptide. Proc. Biochem. 2019, 79, 97-104. [CrossRef]

18. Su, J.; Liao, D.; Su, Y.; Liu, S.; Jiang, L.; Wu, J.; Liu, Z.; Wu, Y. Novel polysaccharide extracted from Sipunculus nudus inhibits HepG2 tumour growth in vivo by enhancing immune function and inducing tumour cell apoptosis. J. Cell. Mol. Med. 2021, 25, 8338-8351. [CrossRef] [PubMed]

19. Lu, Y.; Chi, H.; Li, G.; Chen, Q.; Qiu, J.; Yu, H.; Fang, X.; Chen, X. Study on alkaline extraction process optimization of polysaccharides from coelomic fluid of Phasolosma esculenta and its antioxidant activity in vitro. Sci. Technol. Food Ind. 2021, 42, 204-210.

20. Lin, H.; Zheng, Z.; Yuan, J.; Zhang, C.; Cao, W.; Qin, X. Collagen peptides derived from Sipunculus nudus accelerate wound healing. Molecules 2021, 26, 1385. [CrossRef] [PubMed]

21. Pizzino, G.; Irrera, N.; Cucinotta, M.; Pallio, G.; Mannino, F.; Arcoraci, V.; Squadrito, F.; Altavilla, D.; Bitto, A. Oxidative Stress: Harms and Benefits for Human Health. Oxid. Med. Cell. Longev. 2017, 2017, 8416763. [CrossRef]

22. Sharifi-Rad, M.; Anil Kumar, N.V.; Zucca, P.; Varoni, E.M.; Dini, L.; Panzarini, E.; Rajkovic, J.; Fokou, P.V.T.; Azzini, E.; Peluso, I.; et al. Lifestyle, Oxidative Stress, and Antioxidants: Back and Forth in the Pathophysiology of Chronic Diseases. Front. Physiol. 2020, 11, 694. [CrossRef] [PubMed]

23. Forman, H.J.; Zhang, H. Targeting oxidative stress in disease: Promise and limitations of antioxidant therapy. Nat. Rev. Drug Discov. 2021, 20, 689-709. [CrossRef]

24. Cheung, R.C.; Ng, T.B.; Wong, J.H. Marine peptides: Bioactivities and applications. Mar. Drugs 2015, 13, 4006-4043. [CrossRef]

25. Ruocco, N.; Costantini, S.; Guariniello, S.; Costantini, M. Polysaccharides from the marine environment with pharmacological, cosmeceutical and nutraceutical potential. Molecules 2016, 21, 551. [CrossRef]

26. Lafarga, T.; Acién-Fernández, F.G.; Garcia-Vaquero, M. Bioactive peptides and carbohydrates from seaweed for food applications: Natural occurrence, isolation, purification, and identification. Algal Res. 2020, 48, 101909. [CrossRef]

27. Nwachukwu, I.D.; Aluko, R.E. Structural and functional properties of food protein-derived antioxidant peptides. J. Food Biochem. 2019, 43, e12761. [CrossRef] [PubMed]

28. Kai, W.; Han, L.; Hong, H.; Pan, J.; Liu, H.; Luo, Y. Purification and identification of novel antioxidant peptides from silver carp muscle hydrolysate after simulated gastrointestinal digestion and transepithelial transport. Food Chem. 2021, $342,128275$.

29. Chalamaiah, M.; Dinesh Kumar, B.; Hemalatha, R.; Jyothirmayi, T. Fish protein hydrolysates: Proximate composition, amino acid composition, antioxidant activities and applications: A review. Food Chem. 2012, 135, 3020-3038. [CrossRef]

30. Liu, W.Y.; Zhang, J.T.; Miyakawa, T.; Li, G.M.; Gu, R.Z.; Tanokura, M. Antioxidant properties and inhibition of angiotensinconverting enzyme by highly active peptides from wheat gluten. Sci. Rep. 2021, 11, 5206. [CrossRef] [PubMed]

31. Tadesse, S.A.; Emire, S.A. Production and processing of antioxidant bioactive peptides: A driving force for the functional food market. Heliyon 2020, 6, e04765. [CrossRef]

32. Fernando, I.P.S.; Park, S.Y.; Han, E.J.; Kim, H.S.; Kang, D.S.; Je, J.Y.; Ahn, C.B.; Ahn, G. Isolation of an antioxidant peptide from krill protein hydrolysates as a novel agent with potential hepatoprotective effects. J. Funct. Foods 2020, 67, 103889. [CrossRef]

33. Tonolo, F.; Folda, A.; Cesaro, L.; Scalcon, V.; Marin, O.; Ferro, S.; Bindoli, A.; Rigobello, M.P. Milk-derived bioactive peptides exhibit antioxidant activity through the Keap1-Nrf2 signaling pathway. J. Funct. Foods 2020, 64, 103696. [CrossRef]

34. Zhang, J.; Li, M.; Zhang, G.; Tian, Y.; Kong, F.; Xiong, S.; Zhao, S.; Jia, D.; Manyande, A.; Du, H. Identification of novel antioxidant peptides from snakehead (Channa argus) soup generated during gastrointestinal digestion and insights into the anti-oxidation mechanisms. Food Chem. 2021, 337, 127921. [CrossRef]

35. Zhu, Y.L.; Li, S.D.; Liao, Y.; Li, J.M. Made polypeptide from Sipunculus nudus by papain enzymolysis and its effects on hydroxy radical cleaning. Adv. Mater. Res. 2013, 699, 360-366. [CrossRef]

36. Xiang, H.; Liu, L.; Lu, X.; Shi, Y.; Chen, J. Optimization of the preparation of collagen antioxidant peptide of Phascolosoma esculenta by response surface method. Sci. Technol. Food Ind. 2014, 13, 253-257.

37. Zhang, Q.; Dong, L.; Tong, T.; Wang, Q.; Xu, M. Polysaccharides in Sipunculus nudus: Extraction condition optimization and antioxidant activities. J. Ocean Univ. China 2017, 16, 74-80. [CrossRef]

38. Wu, Y.; Jiang, H.; Lin, J.S.; Liu, J.; Wu, C.J.; Xu, R. Antioxidant, hypolipidemic and hepatic protective activities of polysaccharides from Phascolosoma esculenta. Mar. Drugs 2020, 18, 158. [CrossRef]

39. Li, N.; Shen, X.; Liu, Y.; Zhang, J.; He, Y.; Liu, Q.; Jiang, D.; Zong, J.; Li, J.; Hou, D.; et al. Isolation, characterization, and radiation protection of Sipunculus nudus L. polysaccharide. Int. J. Biol. Macromol. 2016, 83, 288-296. [CrossRef] [PubMed]

40. Chen, L.; Deng, H.; Cui, H.; Fang, J.; Zuo, Z.; Deng, J.; Li, Y.; Wang, X.; Zhao, L. Inflammatory responses and inflammationassociated diseases in organs. Oncotarget 2018, 9, 7204-7218. [CrossRef]

41. Furman, D.; Campisi, J.; Verdin, E.; Carrera-Bastos, P.; Targ, S.; Franceschi, C.; Ferrucci, L.; Gilroy, D.W.; Fasano, A.; Miller, G.W.; et al. Chronic inflammation in the etiology of disease across the life span. Nat. Med. 2019, 25, 1822-1832. [CrossRef] 
42. Lordan, R.; Zabetakis, I. Invited review: The anti-inflammatory properties of dairy lipids. J. Dairy Sci. 2017, 100, 4197-4212. [CrossRef] [PubMed]

43. Yahfoufi, N.; Alsadi, N.; Jambi, M.; Matar, C. The immunomodulatory and anti-inflammatory role of polyphenols. Nutrients 2018, 10, 1618. [CrossRef]

44. Sun, J.; Gou, Y.; Liu, J.; Chen, H.; Kan, J.; Qian, C.; Zhang, N.; Niu, F.; Jin, C. Anti-inflammatory activity of a water-soluble polysaccharide from the roots of purple sweet potato. RSC Adv. 2020, 10, 39673-39686. [CrossRef]

45. Liang, Q.; Chalamaiah, M.; Liao, W.; Ren, X.; Ma, H.; Wu, J. Zein hydrolysate and its peptides exert anti-inflammatory activity on endothelial cells by preventing TNF- $\alpha$-induced NF- $\kappa B$ activation. J. Funct. Foods 2020, 64, 103598. [CrossRef]

46. Wang, Y.; Zhu, H.; Wang, X.; Yu, Y.; Xie, J. Natural food polysaccharides ameliorate inflammatory bowel disease and its mechanisms. Foods 2021, 10, 1288. [CrossRef]

47. Snigdha, G.; Kaustav, M. Structural-features of food-derived bioactive peptides with anti-inflammatory activity: A brief review. J. Food Biochem. 2018, 43, e12531.

48. Zhu, W.; Ren, L.; Zhang, L.; Qiao, Q.; Farooq, M.Z.; Xu, Q. The Potential of Food Protein-Derived Bioactive Peptides against Chronic Intestinal Inflammation. Mediat. Inflamm. 2020, 2020, 6817156. [CrossRef]

49. Seung, Y.L.; Sun, J.H. Antihypertensive peptides from animal products, marine organisms, and plants. Food Chem. 2017, 228 , 506-517.

50. Mirzapour, M.; Rezaei, K.; Sentandreu, M.A. Identification of potent ACE inhibitory peptides from wild almond proteins. J. Food Sci. 2017, 82, 2421-2431. [CrossRef]

51. Ola, A.; Moncef, N. Basic and recent advances in marine antihypertensive peptides: Production, structure-activity relationship and bioavailability. Trends Food Sci. Technol. 2019, 88, 543-557.

52. Abachi, S.; Bazinet, L.; Beaulieu, L. Antihypertensive and angiotensin-I-converting enzyme (ACE)-inhibitory peptides from fish as potential cardioprotective compounds. Mar. Drugs 2019, 17, 613. [CrossRef] [PubMed]

53. Agustina, E.N.; Santiago, S.; Alejandra, V.Q.; Maria, C.A. Amaranth as a source of antihypertensive peptides. Front. Plant Sci. 2020, 11, 578631.

54. Yu, Z.; Guo, H.; Shiuan, D.; Xia, C.; Zhao, W.; Ding, L.; Zheng, F.; Liu, J. Interaction mechanism of egg white-derived ACE inhibitory peptide TNGIIR with ACE and its effect on the expression of ACE and AT1 receptor. Food Sci. Hum. Wellness 2020, 9, 52-57. [CrossRef]

55. Durak, M.Z.; Neslihan, A.T. Antihypertensive Peptides in Dairy Products. Am. J. Biomed. Sci. Res. 2020, 7, 191-195. [CrossRef]

56. Arshdeep, K.; Bababode, A.; Poorva, S.; Deepansh, S.; Sawinder, K. Recently isolated food-derived antihypertensive hydrolysates and peptides: A review. Food Chem. 2021, 346, 128719.

57. Ma, K.; Wang, Y.; Wang, M.; Wang, Z.; Wang, X.; Ju, X.; He, R. Antihypertensive activity of the ACE-renin inhibitory peptide derived from Moringa oleifera protein. Food Funct. 2021, 12, 8994-9006. [CrossRef]

58. Liu, Y.; Zhang, L.; Guo, M.; Wu, H.; Xie, J.; Wei, D. Virtual screening for angiotensin I-converting enzyme inhibitory peptides from Phascolosoma esculenta. Bioresour. Bioprocess. 2014, 1, 17. [CrossRef]

59. Guo, M.; Chen, X.; Wu, Y.; Zhang, L.; Huang, W.; Yuan, Y.; Fang, M.; Xie, J.; Wei, D. Angiotensin I-converting enzyme inhibitory peptides from Sipuncula (Phascolosoma esculenta): Purification, identification, molecular docking and antihypertensive effects on spontaneously hypertensive rats. Proc. Biochem. 2017, 63, 84-95. [CrossRef]

60. Du, L.; Fang, M.; Wu, H.; Xie, J.; Wu, Y.; Li, P.; Zhang, D.; Huang, Z.; Xia, Y.; Zhou, L.; et al. A novel angiotensin I-converting enzyme inhibitory peptide from Phascolosoma esculenta water-soluble protein hydrolysate. J. Funct. Foods 2013, 5, 475-483. [CrossRef]

61. Wu, H.; Liu, Y.; Guo, M.; Xie, J.; Jiang, X. A virtual screening method for inhibitory peptides of angiotensin I-converting enzyme. J. Food Sci. 2014, 79, C1635. [CrossRef]

62. Sun, X.; Wang, M.; Liu, B.; Sun, Z. Purification and characterization of angiotensin I converting enzyme inhibition peptides from Sandworm Sipunculus nudus. J. Ocean Univ. China 2017, 16, 911-915. [CrossRef]

63. Yin, M.; Zhang, Y.; Li, H. Advances in research on immunoregulation of macrophages by plant polysaccharides. Front. Immunol. 2019, 10, 145. [CrossRef]

64. Liang, R. Orthogonal test design for optimization of the extraction of polysaccharides from Phascolosoma esulenta and evaluation of its immunity activity. Carbohydr. Polym. 2008, 73, 558-563.

65. Zhang, C.X.; Dai, Z.R. Immunomodulatory activities on macrophage of a polysaccharide from Sipunculus nudus L. Food Chem. Toxicol. 2011, 49, 2961-2967. [CrossRef] [PubMed]

66. Li, K.X.; Shen, X.R.; He, Y.; Jiang, D.W.; Liu, Y.M.; Hou, D.Y.; Chen, W. Effect of Sipunculus nudus polysaccharides on immunological function in mice. Chin. J. Mar. Drugs 2012, 31, 46-49.

67. Su, J.; Jiang, L.; Wu, J.; Liu, Z.; Wu, Y. Immunologic effect of polysaccharides extracted from Sipunculus nudus (SNP) on Hepatoma HepG2-bearing Mice. bioRxiv 2017, 10, 175190. [CrossRef]

68. Ferlay, J.; Ervik, M.; Lam, F.; Colombet, M.; Mery, L.; Piñeros, M.; Znaor, A.; Soerjomataram, I.; Bray, F. Global Cancer Observatory: Cancer Today; International Agency for Research on Cancer: Lyon, France, 2020; Available online: https://gco.iarc.fr/today (accessed on 5 February 2021).

69. Pucci, C.; Martinelli, C.; Ciofani, G. Innovative approaches for cancer treatment: Current perspectives and new challenges. eCancer Med. Sci. 2019, 13, 961. [CrossRef]

70. Khalifa, S.; Elias, N.; Farag, M.A.; Chen, L.; Saeed, A.; Hegazy, M.F.; Moustafa, M.S.; Abd El-Wahed, A.; Al-Mousawi, S.M.; Musharraf, S.G.; et al. Marine natural products: A source of novel anticancer drugs. Mar. Drugs 2019, 17, 491. [CrossRef] [PubMed] 
71. Alves, C.; Silva, J.; Pinteus, S.; Gaspar, H.; Alpoim, M.C.; Botana, L.M.; Pedrosa, R. From marine origin to therapeutics: The antitumor potential of marine algae-derived compounds. Front. Pharmacol. 2018, 9, 777. [CrossRef]

72. Khan, T.; Date, A.; Chawda, H.; Patel, K. Polysaccharides as potential anticancer agents-A review of their progress. Carbohydr. Polym. 2019, 210, 412-428. [CrossRef] [PubMed]

73. Su, J.; Jiang, L.L.; Wu, J.N.; Liu, Z.Y.; Wu, Y.P. Anti-tumor and anti-virus activity of polysaccharides extracted from Sipunculus nudus (SNP) on Hepg2.2.15. Int. J. Biol. Macromol. 2016, 87, 597-602. [CrossRef] [PubMed]

74. Chen, W.; Wang, X.; Shao, D.; Li, L.; Huang, Y.; Sun, H.; Li, L.; Lin, Y. Study on extraction process of Sipunculus nudus polysaccharide and its antioxidant activity. Agric. Biotechnol. 2018, 7, 112-118. 